\title{
The University of Sydney
}

\author{
Meera Atkinson
}

Australia is a crime scene:

Natalie Harkin's intervention on national numbness and the national ideal

\begin{abstract}
:
Sara Ahmed analyses the construction of the national ideal, conceiving of nationhood as a formation dependent on the stickiness of an ideal-image informed by complex individual and collective physic processes. In this article, I focus on the Narungga poet, artist, and scholar Natalie Harkin's debut collection of poems, Dirty Words, through the lens of Ahmed's work on the socialisation of affect to argue that Harkin's poetics stage an intervention on national numbness (a consequence, in part, of Australia's traumatic establishment as a penal colony) and Australia's Anglo-centric national ideal. I examine Harkin's challenge to those who continue to fly the traumatising, colonising flag and her witnessing to transgenerational trauma in the post-invasion context, showing how her testimony confronts the denial and division entrenched in the national ideal, past and present. Harkin's mediation contributes to a burgeoning First Nations poetics in Australia that demands recognition of Aboriginal and Torres Strait Islander peoples' experience and knowledge, and calls for justice, accountability, reflection, and response from non-Indigenous Australians.
\end{abstract}

\section{Biographical note:}

Meera Atkinson is a Sydney-based scholar, literary writer, and poet. She is the author of The Poetics of Transgenerational Trauma (Bloomsbury 2017), and co-edited Traumatic Affect (2013), an international volume of academic essays exploring the nexus of trauma and affect. Traumata, a literary title about the traumatising nature of patriarchy, is forthcoming on Queensland of University Press (UQP) in 2018. Meera is a sessional teacher in creative writing at The University of Sydney.

Keywords:

Creative Writing - Trauma - Nation - Transgenerational trauma - Affect - Poetic intervention 


\section{Introduction}

Natalie Harkin is a Narungga woman from South Australia who produces academic and literary writing that reveals the national trauma at the heart of colonialism while critiquing the imagined ideal of the Australian nation-state. This article gives focus to Harkin's first book publication, Dirty Words (2015a), which she describes in the Preface as an 'A to Z index of poetry' and a 'contemplation of nation and history' (ix).

Harkin's poetic-affective experiment sets its sights on the colonised national ideal, depicting the contemporary post-traumatic state resulting from a nationhood established by blood. This experimental poetics witnesses to profoundly traumatic events, events that leave as their trace impossibility. Cathy Caruth, following Dori Laub, conceives of this traumatic impossibility, this lack of psychic registration and processing, as the 'gap that carries the force of the [traumatic] event and does so precisely at the expense of simple knowledge and memory' (1996: 7). The remarkable feat of Dirty Words (2015a) is that it witnesses to not one trauma, nor even to the cumulative traumata of an individual, but to incalculable traumas inflicted on Aboriginal and Torres Strait Islander peoples since 1770. As such, it stands as a transgenerational trauma testimony of historical and political import.

Shoshana Felman (1995) defines trauma testimony as pieces of memory

overwhelmed by occurrences that have not settled into understanding or remembrance, acts that cannot be construed as knowledge nor assimilated into full cognition, events in excess of our frames of reference. (16)

Testimony is, according to Felman, 'language in process' that does not 'possess itself as a conclusion', and a 'discursive practice' [italics in original] (16). This aptly describes Harkin's dismantling of the modern mythology of Australia's imagined 'fair go' and the way her poems confront the dissonance of claims to an equitable society, serving as a reality check to ethically comatose non-Indigenous Australians.

Recent estimates suggest Aboriginal Australians are likely to die on average 9.5 years sooner than non-Indigenous Australians (HealthInfoNet 2016). Suicide-a rare occurrence pre-invasion-is now 2.6 times the rate of non-Indigenous Australians (Australian Government Department of Health 2013), and Aboriginal and Torres Strait Islander peoples' youth suicide accounted for $80 \%$ of Australian suicides in 2010 compared with only $10 \%$ in 1991. Incarceration is 13 times that of nonIndigenous citizens. Juvenile detention rates in torturous facilities are 24 times greater. The infant mortality rate is almost double for Aboriginal and Torres Strait Islander parents. Unemployment is 5 times higher than for other Australians. It is estimated that Aboriginal and Torres Strait Islander peoples' children are 8 times more likely to suffer sustained child abuse or neglect (though it needs to be taken into account that these families are also monitored more heavily and frequently than nonIndigenous families) (Australians Together 2016). The crisis may be obvious, but it is far from a priority for most non-Indigenous Australians.

Clearly, there is an urgent need for disruption of this strategic and harmful collective numbness, which, I will argue, operates as a dissociative physic and emotional dulling and absence of discernment intimately bound to a persistent colonialist national ideal. In The Cultural Politics of Emotion (2004), Sara Ahmed conceptualises an affectivity of the national ideal by way of Sigmund Freud's thinking on love and the formation of group identities. Focusing on Freud's assertion that groups are formed through a 
process in which individuals collectively substitute a shared object for an ego ideal, Ahmed demonstrates the means by which a group 'sticks' together (Ahmed 2004: 130). This process determines which lives are grievable, in Judith Butler's parlance (2009), e.g. loveable, part of the group, valued, and which are not. Ahmed describes the nation as love object as 'a concrete effect of how some bodies have moved towards and away from other bodies, a movement that works to create boundaries and borders' (2004: 133). The national ideal is an effect of this tribal idealisation, which elevates some subjects over others, producing a "national character" (what the nation is like)' (Ahmed 2004: 133).

The national ideal of 'Australia' has long elevated its Anglo settlers and their descendants over First Nations peoples and other 'others' via social and institutional structuring and circulations of attitudes, affects, and discourses that promote Australia's national identity as a white Western nation, despite the fact that Aboriginal and Torres Strait Islander peoples inhabited the land for many millennia before the arrival of the First Fleet and that Australia now presents as multicultural. As emerging poet, artist and scholar Natalie Harkin shows, this ideal is far from passive - a great deal of multi-modal labour goes into its maintenance. Policies enacted by parliaments marked by a serious underrepresentation of Aboriginal and Torres Strait Islander peoples, flag waving Reclaim Australia marches, racist cartoons in the national broadsheet, millions of Australians tuning in daily to the bigoted ravings of AM 'Shock Jocks' - multi-modal collective labour toils to perpetually reinforce and re-inscribe a racist, Euro-centric national ideal.

Harkin is part of the Unbound collective, a group of women experimental writers and artists creatively interrogating the state's archives and colonial history, and the 'archival poetics' - research associated with her PhD (2014, 2015b) - responds to her family's official records. This appears to have laid the foundation for what Harkin achieves in Dirty Words. In her Flinders University biography, Harkin describes her project as weaving 'a love of storytelling, activism and resistance-poetics through art and literature' (2017). In an article on this research titled, 'The Poetics of (Re)Mapping Archives: Memory in the Blood' (2014), Harkin declares her intention to work at the intersection of trauma and affect, witnessing and testimony, scholarly research and creative/literary process. Her view of bodily sensation is central to her witnessing to transgenerational trauma: 'These records are our memories and lives; material, visceral, flesh and blood. The State wounds and our records bleed' (4). Harkin's inhabiting of this material in a bodily way in turn generates her writing:

I sit between almost 200 pages

file-note archives

a portion of Nanna's life under State control with tight throat my heart pumps memory-in-theblood I catch my breath—sharp and hold it (2014: 1).

The concept of 'blood memory' is vital to Harkin's thinking and writing. Its origins lie in American Indian literature and it refers to the call for colonised peoples to go back to heritage, to the memory of ancestry, to engage in the act of 'reclaiming and reimagining histories through narrative memory' (6). Harkin writes:

Here, the body (blood) serves as a metaphor for the intergenerational transmission of cultural knowledge and heritage, through individual and collective memory, particularly in the face of enormous loss. (2014: 7) 
This 'enormous loss' in the context of colonialism is, of course, traumatic, and Harkin's practice of blood memory is infused with a hauntological (Derrida 1994) trauma testimony. Harkin describes Dirty Words as poetic-prose informed by blood memory and haunting, but she clarifies elsewhere that the kind of haunting she is explores is not the 'supernatural-paranormal-impossible,' the 'spooky bump-in-thenight' or the 'Aboriginal spirit-worlds' (2014: 92-93). Hers is a Derridian-informed concern with a hauntological process that questions the notion of a static present and closed-off past:

What I am drawn to is a way of knowing that is haunting; a way of theorizing that which is silent, hidden or absent but is nevertheless acutely present and felt. Haunting, in this sense, allows us to interrogate those dimensions of history, including sites of silenced trauma that continue to affect. Here we can write through and beyond remembering: we can recall, research and conjure up stories from places where absence sears through feelings of the uncanny, of recognition and knowing where stories have been hidden and repressed, but inevitably remain. (93)

Marianne Hirsch argues for the viability of second-generation literary trauma testimony via a process she calls 'postmemory' (2008), and I have previously argued for a 'poetics of transgenerational trauma' capable of testifying to trauma transmissions well beyond the second generation (2017). Harkin's poetics, then, emerge as a blood memory witnessing that honours intergenerational transmissions of cultural knowledge and heritage and testifies to colonial trauma and its transgenerational transmissions. As such, it is an act of political resistance, and one aligned with Ahmed's understanding of affective and politicised love.

Hirsch articulates the linkages between various 'posts', trauma and memory in a manner that evokes other "posts' highly relevant to Harkin's poetry. The " post" in "postmemory", Hirsch writes, "signals more than a temporal delay and more than a location in an aftermath' (2008: 106). She cites postmodernity as an example, noting the way it 'inscribes both a critical distance and a profound interrelation with the modern', and she observes that 'postcolonial does not mean the end of the colonial but its troubling continuity' ... (Hirsch 2008: 106). Harkin's testimony combines the witnessing to transgenerational trauma that Hirsch figures in her conception of postmemory, with a critique of the notion that Australia is 'post' colonialism in terms of the national ideal.

Harkin writes from blood (post)memory at a critical distance from the colonised national ideal while revealing its interrelation with a minimised history of profound trauma operative over many generations. Dirty Words attends to the very intersection of 'posts' Hirsch speaks of and in doing so Harkin's poetry makes various corresponding and interconnected moves. It involves a (post)modern modus operandi and aesthetic in the form of metamodernism, which Timotheus Vermeulen and Robin van den Akker (2010) describe as 'characterized by the oscillation between a typically modern commitment and a markedly postmodern detachment' (Para 2). Metamodernism denotes not so much a reaction to modernism as a 'spacetime that is both' (Para 42). A creative practice like Harkin's shifts between and beyond modernist and postmodernist strategies and sensibilities enabling an exposé of the ugly underbelly of Australian postcolonialism; a post-traumatised national condition in which colonialism remains a troubling continuity that routinely re-traumatises First Nations peoples. At the same time, her poetry also confronts the calcifying national numbness that comes from refusing to deal with this ugly underbelly. This is evident in 'Nationalism' (Harkin 2015), which takes 'Australia Day' to task, mocking former 
prime minister Tony Abbott's ludicrous reintroduction of Knight and Dame honours, and highlighting the theatre of publically ceremonialising immigrant citizenship into 'this invented national-family ... Welcome to Team Australia!' (19), while ignoring the human rights abuses routinely perpetuated on Aboriginal and Torres Strait Islander Australians (Sharp and Arup 2009). The poem goes on to evoke John Howard, as prime minister, and the children overboard scandal, journalist Andrew Bolt (referenced obliquely with a simple italicising of his surname prefacing 'the white-gate' to punny effect), and a host of other denial-laden national ironies and hypocrisies.

Noting that countries like Australia are haunted by realities unrecorded by the colonial authorities - the gatekeepers of history-Harkin declares:

I am interested in the disruptive-transformative affects of archival haunting; the interrogation of what is remembered and what is not known; the recovery of the forgotten and the revelation of the act of forgetting; and what transpires in our attempts to disrupt what Toni Morrison refers to as "national amnesia". (2014: 8)

In the preface to Dirty Words (2015a), Harkin refers to her poems as disrupting 'national amnesia', positioning them as 'a reminder that what is (re)produced and (re)presented for general consumption, by institutions of power, is often steeped in myth-making and persistent colonial ideology' (ix). In poem after poem Harkin highlights the untenable choice First Nations people face when required to 'take on' the character of the [colonialised] national ideal (Ahmed 2004: 134), and the way in which they have been forced into the shadows cast by centred whiteness.

Having thoroughly parsed reports from the Board of Anthropological Research based on Norman Tindale's anthropological expeditions, Aboriginal Affairs legislation, and Aborigines Protection Board Annual Reports over the course of a century, Harkin identifies a national narrative 'represented as truth in public discourse and informing the foundations of public policy' that was 'inscribed and articulated as the Aboriginal problem' (2014: 4). At the pulsing heart of this narrative Harkin finds blood, the blood of her ancestors, her grandmother, mapped and measured and assigned a place in the eugenics-driven colonial scheme of things. 'Aboriginal blood and white blood', she writes.

Full-blood and mixed-blood. Half-caste and quarter-caste. Quadroon and octoroon. Sub-human and fully-human. The racialised assumptions underpinning a so-called real and true Aboriginality became absolute on the colonial blood-dilution-scale, and reinforced the actions of government. (4-5)

Aboriginal and Torres Strait Islander peoples have suffered unspeakably as a result of being forced off their land, enslaved on cattle stations, stolen, herded into missions and domestic servitude in order for our present-day national identity to come into being. National amnesia is indeed operative, but there is also a curious inadequacy of collective response, of care, even when non-Indigenous Australians are forced to remember or are confronted with the grim statistics noted at the start of this article. It is not, I propose, just a disruption of national amnesia Harkin enacts in Dirty Words, but also an intervention into national numbness. Before exploring Harkin's poetics further, I offer a tentative account of a national ideal that both proceeds from and reaffirms traumatic avoidance symptoms compounded by Eurocentric attitudes. 


\section{Australia's national ideal and its roots in national trauma}

Ahmed doesn't discuss trauma overtly in her writing on the national ideal, but it is implicitly related in that elsewhere in The Cultural Politics of Emotion (2004) she chooses to focus her discussion of shame on the Australian political context, and specifically the Bringing Them Home report (1997), which detailed the profound trauma inherent in the policies and practices that created 'the stolen generations.' Psychologist and affect theorist Silvan Tomkins figured shame as the most pernicious of affects, casting it as the affect that 'strikes deepest into the heart of man' (1963: 118), and Giorgio Agamben views shame as an animating affect bound to trauma (1997).

Ahmed, who was raised in Australia, focuses on the socialisation of shame, arguing that it is key in the formation of particular types of subjectivities and collections through the work of the national ideal. 'The intimacy of the national idea with an ideal image', she writes, 'suggests the national idea takes the shape of a particular kind of body, which is assumed in its "freedom" to be unmarked' (2004: 132-133). The body associated with the nation of Australia, its emblem, is unmistakably white, and its 'freedoms' are the assumed and unregistered privileges of the Euro-centred subject. Bodies that don't reflect this image 'cannot be recognized in the abstraction of the unmarked' and as such cannot, by degrees depending on a range of factors including ethnic difference, 'accrue value, and become blockages in the economy' (Ahmed 2004: 133).

Australia selectively promotes a contemporary multicultural identity, but whiteness remains the centre from which the 'multi' is measured and Aboriginal and Torres Strait Islander Australians are often backgrounded even in celebrations of multiculturalism. As Aileen Moreton-Robinson puts it, 'In the guise of the invisible human universal, whiteness secures hegemony through discourse by normalising itself as the cultural space of the West' (2004: 78). The initial rise of Pauline Hanson in 1997 from her Queensland power-base as the leader of the One Nation Party, and the successful resurrection of One Nation Party in the 2016 Federal Election, embody a revived nationalism bent on returning to the good old days when white-centredness went unchallenged at the level of mainstream discourse. The problem with national ideals, Ahmed says, lies not with love, but with idealisation, and confusion between the two. When Hanson expresses 'love' for Australia, it is not love in its more meaningful conceptualisations, but an attachment to a blinkered imaginary national ideal that is so vehemently decried and defended. Harkin's blood (post)memory poetics witness to the crimes of the past 229 years and the analogous traumata, asserting First Nations bodies and experience in the face of a nationalism that does not recognise or value them.

Australia is a crime scene. Its early nationhood was founded on terrain stained by blood spilled in massacres and 'skirmishes', blood stopped by introduced disease, blood-ties broken by unethical policies and practices, blood quantum measured by bureaucrats. Though white Australians are often cast as racist and selfish, with some justification, consideration of a divisive kind of national trauma might be in order. This is not to suggest that we are all equally or similarly traumatised, but rather that a long-view of the traumatic establishment of the nation known as Australia may be useful in understanding collective resistance to engaging with both historic and present-day injustices. 
The PTSD Foundation of America website lists a range of post-traumatic symptoms, categorised as 'avoidance symptoms', which resonate with the behavior of Australians en masse regarding Aboriginal and Torres Strait Islander peoples' trauma and lived realities. Traumatised individuals 'feel numb, emotionless, withdrawing into themselves trying to shut out the painful memories and feelings' (2016). Judith Herman, a leading authority on trauma, interviewed a U.S. combat veteran of the Second World War who reported that numbness is commonplace in warfare:

Like most of the 4th, I was numb, in a state of virtual disassociation. There is a condition ... which we called the two-thousand-year-stare. This was the anesthetized look, the wide, hollow eyes of a man who no longer cares. (1997: 31)

Herman goes on to say that the dissociative symptoms of trauma are detached states of consciousness in the vein of the hypnotic trance. She describes further characteristics of this state as:

surrender of voluntary action, suspension of initiative and critical judgment, subjective detachment or calm, enhanced perception of imagery, altered sensation, including numbness and analgesia, and distortion of reality, including depersonalization, derealization, and change in the sense of time. (37)

Bessel Van der Kolk, another expert in clinical trauma studies, also noted that traumatised people tend to, 'have a poor tolerance for arousal, to respond to stress in an all-or-nothing way, and to feel emotionally numb' (1991: para 8). While Van der Kolk's focus was on the biological mechanisms at play in traumatic experience, and such research is individualistic in orientation, it is interesting to consider traumatic avoidance symptomology, at least in metaphoric terms, in relation to Australian collective consciousness, and to reflect on the ways this numbness might manifest and disseminate in public discourse it is necessary to outline its probable genesis.

Australia's nationhood was quite literally established by crime. Recorded criminals peopled the British penal colony, even if many were only guilty of the pettiest of crimes under the most dire and disadvantaged circumstances. Traumatised by displacement, and likely traumatised before they set sail from the motherland, the first white Australians were, for the most part, poor, uneducated working class people cast out of British society. Having survived the treacherous journey, they were forced to work off their sentence and make a life here after they had done so. Australia is, in a sense, a country of the 'two-hundred-and-twenty-nine-year-stare', communally avoiding traumatic memories of our colonial history, dissociated, and lacking sufficient and sustained initiative and critical judgement in so far as the endemic suffering of Aboriginal and Torres Strait Islander others are concerned. In anticipation of \#notallaustralians objections, I note that many non-Indigenous Australians $d o$ care, and that numerous worthy initiatives have been implemented in an attempt to address the ongoing legacy of colonial trauma, racism and discrimination, but these efforts fall short of creating change at an ideological level, of realising formal 'reconciliation' aspirations, and of birthing a truly post-colonial and First Nations inclusive national ideal. And the fact remains that many Australians are wholly unengaged with the history and lived experiences of First Nation Australians.

Questions as to Australia's exhibiting post-traumatic avoidance symptoms are destined to remain speculative in that there is no collective biology to monitor or screen as researchers do in traditional trauma studies, and Diagnostic and Statistical Manual (DSM) psychological categories are contentious enough without attempting to apply them to society as a whole, but just as Katrina Schlunke has referred to 
places in the Australian landscape affectively charged with the traumatic losses of colonialism as 'dumb places' (2004), I conceive of Australia as a 'numb place'; a place in which the traumatic legacy and strategy of numbness in the course of colonial inhabitancy fused with transgenerationally transmitted imperialist racism to become a calcified avoidance of ethical responsibility to Aboriginal and Torres Strait Islander peoples.

\section{Harkin's poetic-affective intervention}

In 'Dumb places' (2004), Schlunke attempts a reading of place via the senses in response to limited access to confirmed cognitive knowledge. In a similar sense, Dirty Words enacts a bold poetic-affective intervention on national numbness.

Howard's tenacious refusal to apologise to the 'stolen generations' and their communities in the wake of the Bringing Them Home report was an overt manifestation of denial, numbness, and imperialist attitude, and successive governments have failed to deliver adequate, tangible follow up to Kevin Rudd's long-awaited apology in 2008, issued as his first official act as prime minister and Howard's successor. It comes as no surprise, then, that Harkin begins her indexical testimony with a poem titled 'Apology' (Harkin 2015a: 1), which surprises because though this word now evokes the stolen generations, the poem focuses instead on the toxic effects of uranium mining in Kakadu. In this poem, Kakadu traditional owners proffer an 'apology' to the Japanese Prime Minister in the wake of Fukushima, but the final line also implicates Rudd's stolen generation apology:

'while Coalition-Governments mock unmoved by another Sorry' (1).

Ghosting (hauntologically speaking) the poem is the unuttered but warranted apology of government-corporate coalitions whose economically driven push for continued mining in the region has disregarded objections by some traditional owners and ill effects in the community.

Under 'M', Harkin's 'Mythology' (2015a: 18) is set out in jagged columns in which white space does as much work as the words. This strategy is a notable aspect of Harkin's poems, gesturing toward the aporia within trauma testimony, the way in which it can never quite be complete. Citing Laub's figuring of the 'gap' within trauma - that moment between the event of trauma and its incomplete psychic registration - as 'the collapse of witnessing', Caruth maintains that this aporia, this unknowability, 'opens up and challenges us to a new kind of listening, the witnessing, precisely, of impossibility' (Caruth 1995: 10). 'Gap' is also a word often used to describe the multifaceted inequality between Aboriginal and Torres Strait Islander peoples and non-Indigenous Australians (Australians Together 2016), and in Harkin both gaps-white space traumatic aporia and the reverberating transgenerational disadvantages resulting from the gulf between white Australians and First Nations peoples - are mapped over each other revealing their interrelatedness. Thus Harkin testifies to the impossibility of comprehending the transgenerational traumata of colonialism for the Aboriginal and Torres Strait Islander peoples of Australia. This is traumata not just operative in the period of invasion and colonial establishment, but continually compounded by neo-colonialisms that reinscribe Australia as white, as Western, through the nation ideal, thereby negating First Nations culture and history and the possibility of creating a unique nation in partnership with Aboriginal and 
Torres Strait Islander peoples.

'Mythology' is prefaced with a 2014 quote by Abbott, when he was still the Prime Minister of Australia, stating, and then forcefully reiterating, that the arrival of the First Fleet was 'the defining moment in the history of this continent'. The poem features various kinds of repetitions, including anaphora, that skilfully convey a rhythmic and musical, incantatory, quality. Some words are written in italics, the most commonly repeated phrase among them being echo of words, which appears in italics and plain text. The poem contrasts words and phrases from multiple points of view and registers, including colonial readings of Aboriginal and Torres Strait Islander peoples, such as 'they eat their children', 'fauna-and-flora', 'it's for the best', and 'The Aboriginal Problem.' These run along side, above, or below other words and fragments: 'float of words', 'anchored mythology', 'old-sweeping narratives', 'writing into itself', and 'blood-quantum-identities' to create a poem of layered potency. Harkin creates and sets out her charged poetics by presenting texts on official and public record in such a way as to expose their characteristic racism and lyrically witness to its negative effects. Affect is crucial to that critique in that it is central to trauma being conceptualised in art as a social force. As Jill Bennett puts it, certain kinds of art help us understand trauma as a "political rather than a subjective phenomenon' [italics in original] (2005: 12).

Melissa Gregg and Greg Seigworth (2010) describe affect as being synonymous with force or forces of encounter, even if this force often 'transpires within and across the subtlest of shuttling intensities' proceeding by way of an 'ever-modulating forcerelations-that rises and falls not only along various rhythms and modalities of encounter' operative in both sense and sensibility (2). Harkin's body and senses are palpably at work in her poems. She is not just thinking-writing, she's listening to speeches, watching $\mathrm{TV}$, reading the papers, searching the records, talking to her family, remembering her aunts (the poem titled 'Resistance' under R pays homage to her aunties - women whose stories, knowledge and bodies have marked and sustained her). She's feeling it in every word, every sentence, every poem. Seigworth and Gregg state:

At once intimate and impersonal, affect accumulates across both relatedness and interruptions in relatedness, becoming a palimpsest of force-encounters traversing the ebbs and swells of intensities that pass between "bodies" (bodies defined not by an outer skin-envelope or other surface boundary but by their potential to reciprocate or co-participate in the passages of affect). (2)

Harkin's poetic index, both intimate and impersonal, accumulates cross-cultural relatedness and failures of relatedness, becoming a palimpsest of force-encounters in which testimony traverses intensities passing between bodies; individual, organisational, political, and textual. Two poems in particular show how the national ideal constructs a defensive narrative, publically performed, in which national celebration flourishes while in the background 'racial others become the obstacle that allows the white subject to sustain a fantasy that without them, the good life would be attainable' (Ahmed 2004: 131).

'Tall Ships' (Harkin 2015a: 34) is a lament about the way in which the denial of colonial and neo-colonial criminality is reinforced in carefully orchestrated contagions of national pride: 
Old boats

elicit great excitement

heady feverish

national pride

old boats

re-enact silence

as frontier-myths

glide

into tomorrow

And in another poem titled 'Union Jack' (35), Harkin questions the circulation of the icons and objects that 'exult colonial Australia'. The middle passage reads:

Australia-Day incites

southern-crossed-biceps

flag-flying-fever

tall-ship-nostalgia

Honours for an English-Prince

salutes to the Queen

The frequent italics in Harkin's work are significant, a constant reminder of the constructivist nature of national narrative. Tall ship nostalgia is presented as merely one way in which the 'whiteness' of Australia and its colonised national ideal is reinscribed as Aboriginal and Torres Strait Islander peoples are, in the same movement, erased.

Moreton-Robinson critiques the academy for its tendency to cast Aboriginal and Torres Strait Islander scholars as 'native informants' useful for providing 'experience' to white scholars long 'positioned as the leading investigators of the lives, values and abilities of Indigenous people' (2004: 85). In academia, Moreton-Robinson points out, 'it is rarely considered that Indigenous people are extremely knowledgeable about whites and whiteness' (85). Thinkers and writers like Harkin have important knowledge and valuable contributions to make to understandings about the nation and the whiteness-centred neo-colonialisms that still dominate, despite rhetorical lip service to consultation and the multiculturalism. In her scholarly writing, Harkin notes that the 'history-as-battleground debates are played out largely between white historians', who are often politically motivated and who omit Aboriginal and Torres Strait Islander voices, an omission that ensures the objectification of First Nations people (2014: 9). Dirty Words cuts right through the 'history wars' with a poetics that both refuses the terms of the debate and rejects its objectifications.

Harkin's writing of Aboriginal peoples' trauma is significant for all the reasons she identifies in her academic writing $(2014,2015 b)$, but what is vital for non-Indigenous scholars to acknowledge is that her work exposes national trauma, constitutive of and thus inseparable from the national ideal itself. Witnessing to endemic suffering denied and minimised under the guise of 'protection', Harkin also reveals splitting and fracturing in the national psyche, challenging a national ideal that sidelines the wealth 
of First Nations knowledges and contributions and that refuses or underperforms its responsibility to wrangle with the shame of wrongdoings and indifference, that is, in other words, shameless.

As Ahmed observes, the 'shame of the nation' and the 'shame of its refusal of shame' are a complicated business involving circulating 'affective economies' and affectword binds issued by way of political speeches, journalistic coverage, and public commentary that make up dominant discourses (2004: 120). When it comes to colonial trauma, it has been commonplace for public expressions of shame to be staged with the agenda of converting shame to pride, thereby restoring the established national ideal. The confrontational nature of Harkin's poetry is, much like the 'indigenous others' who demanded the government apologise on behalf of the nation in the wake of the Bringing Them Home report, a political act that exposes injustice and 'the history of violence to others' (Ahmed 2004: 119). It refuses the mainstream refusal of shame that safeguards the national ideal and its marginalisation of Aboriginal and Torres Strait Islander peoples. And its indexical nature shows how this ideal has systematically done violence by scapegoating First Nations communities and individuals for experiencing the consequences of socially and politically enacted trauma transmissions.

There are two noteworthy aspects of the indexical structure of Dirty Words. The first is the way it evokes her time in the archives, where categorisation, such as by alphabetisation or other modes of structuring, are characteristic of the information systems she has so diligently studied. Harkin works this reference by knowingly coopting the colonial information system strategy of alphabetising to revolutionary ends.

The second relates to her alphabetical poetic experiment, to her attending to each letter of the alphabet and responding with a poem. This seems an especially significant semiotic move, in that claims around the representation of language (usually around difficulty or resistance regarding linguistic representation) have been central in trauma theory. As Caruth and other literary trauma theorists have maintained, 'It is the fundamental dislocation implied by all traumatic experience that is both its testimony to the event and to the impossibility of its direct access' (Caruth 1995: 9).

This raises the question of how a writer might testify to traumata on the magnitude experienced by Australia's Aboriginal and Torres Strait Islander peoples over many generations while also critiquing a national ideal that discounts that suffering. Harkin tackles it with hybrid experimentation, part repurposed official record, part found poetry, and part skillful generative poetics that in combination have the effect of shaking loose affect bound to trauma; affect which, unstirred, remains distant, numbed.

Some of the most moving poetry in Dirty Words deals with the servitude of women and girls, the exploitation of womenfolk like her grandmother. In the 'D: Domestic' section, Harkin clusters several poems witnessing to this enslavement via a poeticprose re-arrangement of texts from the South Australian Royal Commission on the Aborigines, 1913, the Australian Aborigines Progressive Association, 1928, and an article titled, 'The Ways of the Abo. Servant' by one Helen Colman. 
In one particularly wrenching nearby passage Harkin writes:

\author{
Aborigines Protection Board \\ Committed to Institution till 18 years \\ Charged 'Destitute' \\ Age 8
}

She is very fond

\title{
of her own people
}

and is looking forward

to going home

(Harkin 2015a: 6)

The italicised, step-spaced phrasing generates a heartbreakingly poignant rhythm and aesthetic carried by Harkin's embodiment of sensation. Such a witnessing, maintains Bennett, can be considered 'empathic vision' (2005: 21).

In another poem in that section titled, 'Apron Sorrow', Harkin unfolds traumatic affect from the creases and pockets of the linen in which the women labour:

$$
\begin{aligned}
& \text { apron-folds and pockets keep secrets } \\
& \text { pinned tucked hidden } \\
& \text { they whisper into linen-shadows } \\
& \text { that flicker-float with the sun } \\
& \text { hung } \\
& \text { limp on the breeze they sway } \\
& \text { a rhythmic } \\
& \text { sorrow (7) }
\end{aligned}
$$

The gapped imagery of washed aprons swaying with the sorrow of slavery represent a testimony comprised of memory overwhelmed by traumatic experience not yet understood or 'settled into remembrance' (Felman 1995). Here Harkin is witnessing to 'acts that cannot be construed as knowledge nor assimilated into full cognition', to events outside our 'frame of reference', and for this reason, the testimony cannot offer a complete statement or total account of the events themselves and 'does not possess itself as a conclusion' (Felman 1995: 16). 


\section{Conclusion: cross-cultural solidarity}

As Stef Craps (2012) points out, the conventional wisdoms espoused by Caruth, Felman et al. in founding trauma theory texts fall short when it comes to the matter of cross-cultural ethical engagement. According to Craps, literary trauma theorists have traditionally failed on four counts:

they marginalize or ignore traumatic experiences of non-Western or minority cultures, they tend to take for granted the universal validity of definitions of trauma and recovery that have developed out of the history of Western modernity, they often favour or even prescribe a modernist aesthetic of fragmentation and aporia as uniquely suited to the task of bearing witness to trauma, and they generally disregard the connections between metropolitan and non-Western or minority traumas. (1)

Most of the major works of trauma theory focus on traumatic social and political events in Europe. While this is doubtless due, in part, to its emergence from Holocaust Studies, trauma scholars in a country like Australia have much to tend to closer to home. The opportunity for 'cross-cultural solidarity', as Craps puts it, means subverting the Eurocentric bias of trauma theory. It also means listening to and reading Aboriginal and Torres Strait Islander writers and theorists and acknowledging their vital contribution to Australian literature, with appreciation for its heightened capacity for cross-cultural transgenerational trauma testimony.

Apart from beginning to rectify a meaningful oversight in trauma theory, there is a good deal engagement with this testimony can show us about both the country we live in and the experience of its original inhabitants now cast as 'other.' Such testimony obliges non-Indigenous Australians to question our complacency and complicity, and to reflect on the ways in which we might rouse up from our posttraumatic-meets-privilege slumber to not only fulfil our duty to First Nations people, but to learn from them in how we relate to this country we came to call home.

Harkin targets numerous leaders and public figures, with sizeable followings among the citizenry, who deny the realities to which she testifies for breeding ignorance and arrogance. Many details of the crimes of the past 229 years were not recorded, and some remain withheld at the level of public record. And as is the case with many crimes, much will forever be unknowable to those of us who live in their wake. But what is knowable is that Harkin's reckoning in Dirty Words with the 'impossibility' of the severe and sustained traumata inflicted on Australia's Aboriginal and Torres Strait Islander peoples and the denial and numbness of 'white' Australia is no small matter poetically or politically, despite her humility in referring to her poetic-prose as 'a compelling kind of affective-connectivity and deep knowing through my own family story' (Harkin 2015b: 92). Harkin's testimony deserves to be widely read, to be discussed, not just as a representation of First Nations realities, but as a treatise on the state of the nation, as a poetic-affective intervention that asks white readers and scholars to relax defenses, to emerge from complacent numbness, to feel, and to learn from her cross-cultural witnessing.

To do this, Australians, as individual citizens and as a collective, must refuse the 'over-valuation of the nation as a love object' (Ahmed 2004: 134) - the national ideal associated with colonised idealisation (140) that restricts ideality to certain subjects (Silverman 1996: 37). Ahmed points out that love and idealisation are not the same, though they are involved in mutual production, and she cautions against the complications of claims to love in politics, to its potential to challenge power relations (2004: 141). 'Love', she says, matters most 'as a way of describing the very 
affect of solidarity with others in the work that is done to create a different world' (141). This is, Ahmed notes, what Jodi Dean calls 'reflective solidarity' which proceeds as 'open-ness to difference' (Dean 1996: 17).

There is a limit to what literature can accomplish, and there are those who argue against it having any political agency, but they overlook two crucial points: the importance of language in addressing trauma and the importance of affect when it comes to ethical engagement. Traditional trauma theory positioned trauma as a purely physic phenomena of a non-representable nature. This conflicts with Van der Kolk's assertion that 'language gives us the power to change ourselves and others by communicating our experiences, helping us to define what we know, and finding a common sense of meaning' (2014: 49) in the face of trauma. And as far back as the 17th century the philosopher Benedict de Spinoza (1996) made connections between affect and ethics that have proven enduring and highly productive, informing the 'affect turn' of the 2000s. Spinoza conceived of affect as necessary to 'increase or aid our body's power of acting' (1996: 78), and in turn he saw this as necessary for ethical motivation and communal care. According to Spinoza's reasoning, affect, as operative in artistry, has the potential to disrupt numbness. Harkin puts it this way:

Literary practice and the arts offer a space to interrogate the many facets of the racialised archive and its role in forming national consciousness and identity. We can identify the conditions that produce a recycling and reinvigoration of the colonial archives and expose the state's attempts to bury traumatic episodes of history that, without some kind of healing and positive transformation, will inevitably return to haunt. (Harkin 2015b: 9)

Australian First Nations literary testimony has become a force to be reckoned with, and it is attracting both national and international accolades. Harkin's fellow Adelaideian, poet and visual artist Ali Cobby Eckermann, a Yankunytjatjara/Kokatha woman, recently won the prestigious Windham-Campbell Prize, worth A $\$ 215,000$, which is administered by Yale's Beinecke Rare Book \& Manuscript Library. Alexis Wright, a member of the Waanyi nation of the Gulf of Carpentaria working in experimental fiction, has won a slew of significant prizes, including the Miles Franklin Award, the Queensland Premier's Literary Awards, and the Australian Literature Society ALS Gold Medal, and Lionel Fogerty is an award-winning poet who hails from Queensland. Melissa Lucashenko, Ellen van Neervan, Tara June Winch, Tony Birch, Bruce Pascoe, Kim Scott, Evelyn Araluen ... too much talent and testimony to note, but one thing is certain: First Nations writers command and deserve attention.

I view poetic-affective interventions such as these as political acts and activisms that confront numbness via an anti-colonial transgenerational trauma testimony. As Ahmed states:

Emotions show us how histories stay alive, even when they are not consciously remembered; how histories of colonialism, slavery, and violence shape lives and worlds in the present.' (2004: 202)

If 'justice involves feelings' (Ahmed 2004: 202), being moved in sufficient numbers by reading such testimonies might help pave the way for a reimagining of nationhood and national identity. Australia is a crime scene, and the poetics of the likes of Harkin, Eckermann, and Wright proceeds like a cross between an elegy and a rally cry, demanding two things from us, its readers: a willingness to face and feel the grief at the tender centre of our national numbness, and the subsequent motivation to take, 
and demand, ethical action.

I have written this article as a form of action, with the intention of exploring, by scholarly means, the significance of Harkin's testimony in the hope of encouraging more readers to her and increased awareness of the operations she testifies to toward their being transformed. It is in the spirit of dialogue that my reading of Dirty Words responds to Harkin's project to 'unsettle and be brave; to not be silent ...' (2015a: ix) in an attempt to pay respect to her work and the generations of pain and resilience it speaks to.

'There is still work to be done, and difficult conversations to have', writes Harkin toward the end of her preface. 'Hidden stories can be honoured, exposed and shared, and there is always poetry' (2015a: ix).

\section{Works cited}

Agamben, Giorgio 2000 Remnants of Auschwitz: the witness and the archive, D. Heller-Roazen (trans), New York: Zone Books

Ahmed, Sara 2004 The cultural politics of emotion Oxford: Routledge

Atkinson, Meera 2017 The poetics of transgenerational trauma New York: Blooomsbury

Australian Government Department of Health 2013 Aboriginal and Torres Strait Islander suicide: origin, trends and incidence', at

http://www.health.gov.au/internet/publications/publishing.nsf/Content/mental-natsisps-strattoc $\sim$ mental-natsisps-strat-1 mental-natsisps-strat-1-ab (accessed 10 October 2016)

Australians Together 2016, 'The gap: Indigenous disadvantage in Australia', at http://www.australianstogether.org.au/stories/detail/the-gap-indigenous-disadvantage-in-australia (accessed 10 October 2016)

Bennett, Jill 2005 Empathic vision: affect, trauma, and contemporary art, Stanford, CA.: Stanford University Press

Brennan, Teresa 2004 The transmission of affect, New York: Cornell University Press

Butler, Judith 2009 Frames of war: when is life grievable? New York: Verso

Caruth, Cathy 1996 Unclaimed experience: trauma, narrative, and history, Baltimore: Johns Hopkins University Press

Caruth, Cathy (ed) 1995 Trauma: explorations in memory Baltimore: Johns Hopkins University Press Craps, Stef 2012 Postcolonial Witnessing Basingstoke, UK: Palgrave Macmillan

Dean, Jodi 1996Solidarity of strangers: feminism after identity politics Berkeley: University of California Press.

Derrida, Jacques 1994 Spectres of Marx, P. Kamuf (trans), New York: Routledge

Felman, Shoshana 1995 'Education and crisis, or the vicissitudes of teaching', in C. Caruth (ed) Trauma: Explorations in Memory, 13-60, Baltimore: Johns Hopkins Press

Gregg, Melissa and Gregory J Seigworth (eds) 2010 The Affect Theory Reader Durham: Duke University Press

Harkin, Natalie 2017 'Biography', Flinders University, at http://www.flinders.edu.au/people/natalie.harkin (accessed 19 July 2017)

Harkin, Natalie 2015a Dirty Words Melbourne: Cordite Books 
Harkin, Natalie 2014 'The poetics of (re)mapping archives : memory in the blood' Journal of the association for the study of Australian literature 14 (3), 1-14

Harkin, Natalie 2015b “'I am small at the wharf's edge": The poetic place of haunting' in F Foley, L. Martin-Chew and F. Nicoll (eds) Courting blakness: recalibrating knowledge in the sandstone university. St Lucia: University of Queensland Press, 88-99

HealthInfoNet 2016, 'Mortality', at http://www.healthinfonet.ecu.edu.au/healthfacts/overviews/mortality (accessed 10 October 2016)

Herman, Judith 1997 Trauma and recovery: the aftermath of violence - from domestic abuse to political terror, New York: Basic Books

Hirsch, Marianne 2008 'The generation of postmemory’, Poetics Today 29 (1), 103-128

Moreton-Robinson, Aileen 2004 Whitening race: essays in social and cultural criticism Canberra: Aboriginal Studies Press

PTSD Foundation of America 2016 'PTSD self-assessment test', at http://ptsdusa.org/what-is-ptsd/gethelp/ (accessed 19 October 2016)

Schlunke, Katrina 2004 'Dumb places’ BALAYI: culture, law and colonialism 6, 72-81

Sharp, Ari and Tom Arup 2009 'UN says aboriginal health conditions worse than third world' The Sydney Morning Herald, 5 December, at http://www.smh.com.au/national/un-says-aboriginal-healthconditions-worse-than-third-world-20091204-kay8.html (accessed 19 April 2017)

Silverman, Kaja 1996 The threshold of the visible world Oxford: Routledge

Spinoza, Benedict de 1996 in E. Curley (ed.), Ethics, E. Curley (trans), London: Penguin Books

Tomkins, Silvan 1963 Affect imagery consciousness: the negative affects, Vol. 2, New York: Springer Publishing

Van der Kolk, Bessel 2014 The body keeps the score: brain, mind, and body in the healing of trauma EPUB: Penguin Books Ltd

Van der Kolk, Bessel and Jose Saporta 1991 'The biological response to psychic trauma: mechanisms and treatment of intrusion and numbing' Anxiety Research (U.K.) 4, 199-212, at http://www.cirp.org/library/psych/vanderkolk2/ (accessed 19 October 2016)

Vermeulen, Timotheus and Robin van den Akker 2010 'Notes on Metamodernism' Journal of Aesthetics and Culture 2, 1-14 DOI: 10.3402/jac.v2i0.5677

Wilkie, Meredith 1997 Bringing them home: report of the national inquiry into the separation of Aboriginal and Torres Strait Islander children from their families Sydney: Human Rights and Equal Opportunity Commission 